\title{
Kepentingan Indonesia Dalam Meratifikasi Perjanjian Paris
}

\author{
Posmanto Marbun \\ posmanto_cayo@yahoo.com
}

\begin{abstract}
Paris Agreement as one of global environmental political instruments by involving various actors, had used every countries to attain their interest. However, Paris Agreement faces conflict between country groups. Indonesia complied with the Paris Agreement because of wishing for climate funding for development interest, one of which is by utilizing peatland and establish a Peat Restoration Agency. The methodology used in this paper that is qualitative method by literature review. This paper attemps to explain Indonesia various actions after ratified the Paris Agreement.
\end{abstract}

Keywords : actor; interest; funding; development; peatland.

\begin{abstract}
ABSTRAK
Perjanjian Paris sebagai salah satu instrumen politik lingkungan global dengan melibatkan berbagai aktor, telah dimanfaatkan setiap negara-negara untuk mencapai kepentingannya. Namun, Perjanjian Patis menghadapi konflik di antara kelompok negara. Indonesia mematuhi perjanjian Paris karena menginginkan pendanaan iklim untuk kepentingan pembangunan, salah satunya dengan memanfaatkan lahan gambut dan membentuk Badan Restorasi Gambut. Metodologi yang dipergunakan dalam tulisan ini yaitu metode kualitatif yang menggunakan teknik studi kepustakaan. Penulisan ini mencoba untuk menjelaskan berbagai tindakan Indonesia setelah meratifikasi Perjanjian Paris.
\end{abstract}

Kata Kunci : aktor; kepentingan; pendanaan; pembangunan; lahan gambut.

\section{PENDAHULUAN}

Perjanjian internasional adalah instrumen dari transaksi internasional (Tsani, 1990, p. 64). Perjanjian Paris menggambarkan babak baru aksi lingkungan telah dikuti oleh empat tanda yaitu : menetapkan suatu jalan kecil yang jelas untuk emisi masa depan, mengakui dampak resiko dari dampak iklim, menggeser pendanaan ke arah rendah karbon, pembangunan berkelanjutan dengan fondasi yang kuat (Morgan, 2015). Selama 44 tahun (1972-2016), politisi dan aktivis lingkungan memperjuangkan kepentingannya melalui berbagai perundingan hingga akhirnya menghasilkan semboyan 'berpikir global, bertindak lokal' (Think Globally, Act Locally) (Jurnal Bumi, 2016).

Pemikir green politics (politik hijau) mengusulkan bahwa semboyan tersebut, dapat terwujud dengan mendobrak struktur kekuasaan global kepada tindakan lokal dan pembentukan masyarakat politik serta swadaya ekonomi dalam skala yang lebih kecil 
(Burchill \& Linklater, 2009, p. 345). Hal ini berarti terdapat penolakan, dan menuding penyebab masalah lingkungan adalah struktur yang ada dan para state-actor berusaha tetap ingin mengeksplorasi lingkungan serta sumber daya alam.

Sedangkan, liberal institusionalism/neo-liberalism yang mengusung teori modernisasi berpendapat bahwa pembangunan adalah pertumbuhan ekonomi yang dalam prosesnya termasuk mekanisasi waktu dan industrialisasi (Pieterse, 2010, p. 6). Liberal institusionalism berpandangan institusi internasional memiliki peran penting dalam menciptakan kerjasama antarnegara (Ashari, 2015, p. 312). Jadi, neo-liberalism menerima framework berdasarkan struktur politik maupun nilainilai dunia yang ada sekarang ini. Tujuannya, ingin memperbaiki lingkungan sehingga pembangunan dapat berjalan tanpa membawa dampak negatif dengan menawarkan rezim lingkungan internasional sebagai solusinya.

Lambatnya aksi nyata dari negara maju dan berkembang mengurangi emisi GRK, berdampak pada peningkatan suhu di Bumi. Pada awal tahun 2015, suhu udara menembus rekor global dengan peningkatan rata-rata temperatur $0,85{ }^{\circ} \mathrm{C}$ (Christine, 2015). Diperkirakan, suhu di Bumi berpotensi mengalami kenaikan sebesar $4{ }^{\circ} \mathrm{C}$ apabila ketiadaan tindakan negara-negara menangani perubahan iklim (The World Bank, 2012). Oleh sebab itu, Perjanjian Paris mendapat dukungan sebanyak 195 negara dan terdapat 89 negara yang telah melakukan ratifikasi termasuk Indonesia (Kementerian Luar Negeri Republik Indonesia, 2016). Namun, di balik tindakan negara-negara termasuk Indonesia dalam meratifikasi Perjanjian Paris memiliki kepentingan nasional yang terselubung.

\section{PEMBAHASAN}

\section{Dinamika Perjalanan Perjanjian Paris}

Sebelum terbentuknya Perjanjian Paris, perjanjian internasional lingkungan hidup dalam berbagai tingkat atau derajat kepentingnya telah ada sebelumnya. Salah satu perjanjian internasional lingkungan paling kompleks, yang melibatkan banyak pihak dan rangkaian negoisasi yang panjang yaitu United Nation Framework Convention on Climate Change (UNFCCC). UNFCCC merupakan perjanjian internasional yang tidak mengikat, bertujuan untuk mengurangi emisi GRK di atmosfir, dan negara maju memiliki tanggung jawab yang lebih besar untuk mencapai tujuan tersebut (Maryam, 2011). Perkembangnya, UNFCCC menjadi suatu lembaga internasional independen untuk meningkatkan kerjasama secara berkesinambungan melalui pertemuan bilateral dan multilateral dengan melibatkan sejumlah aktor non-negara dan perwakilan resmi antarnegara. 
UNFCCC mengadakan pertemuan dua tahun sekali yang dihadiri pihak kedua Conference of the Parties (COP). Agenda COP untuk meninjau ulang perkembangan perjanjian, mengadaptasi pemecahan masalah, menegosiasi perkembangan terbaru yang dimasukkan ke dalam kesepakatan berupa protokol (Guerrero, 2011). Pada tahun 1997, COP telah menghasilkan protokol yang fenomenal, yaitu protokol Kyoto sebagai pendekatan kepentingan mengatur pengurangan emisi GRK yang dihasilkan setiap negara anggota terutama negara maju (WWF, 2017).

Adanya kepentingan yang berbeda dan rendahnya kepatuhan negara-negara penyumbang GRK, menyebabkan implementasi protokol Kyoto tidak berjalan dengan efektif. Terlihat dari sikap negara-negara seperti : Cina, Australia dan Amerika Serikat yang menolak meratifikasi protokol Kyoto (IESR, 2011). Lagi pula Kanada memutuskan keluar dari keanggotaan, namun negara Jepang, Rusia, dan Selandia Baru tetap menjadi anggota akan tetapi tidak berkomitmen menurunkan emisi pada periode kedua (Syafputri, 2012).

Setelah kegagalan protokol Kyoto menagih langkah negara maju mengurangi emisi GRK, pada tahun 2007 UNFCCC berhasil menghasilkan kesepakatan Bali Roadmap dan mengadopsi Bali Action Plan (BAP) (Lova, 2013). Road map adalah "peta" yang menjelaskan bagaimana sistem dan strategi dalam menyikapi perubahan iklim global pasca pertemuan UNFCCC di Bali (Winarno, 2011, p. 161). Selama negoisasi berjalan, kesepakatan berkonsentrasi pada empat kunci isu : kelonggaran (mitigation), adaptasi (adaptation), alih teknologi dan penyebaran (technology transfer \& deployment) serta pendanaan (financing) (Carpenter, 2008, p. 7).

Namun, berbagai organisasi lingkungan internasional tidak puas terhadap kesepakatan yang ada karena tujuan dan penetapan target konkrit reduksi emisi gas rumah tidak jelas (DW, 2007). Mereka berkeyakinan bahwa, akan ada suatu perjanjian internasional yang mengatur lebih detail point-point kesepakatan dengan tingkat keberhasilan yang cukup tinggi. Oleh sebab itu, UNFCCC kembali bersidang di Peru dengan mengadopsi suatu draft perjanjian yang lemah yaitu Seruan Lima untuk Aksi Iklim (Lima Call for Climate Action) (Peterman, 2014).

Perundingan ini digagas oleh Ad Hoc Working Group on Durban Platform for Enhanced Action (ADP), yang berhadapan dengan proses pencapaian kesepakatan (perjanjian) baru untuk disepakati di Paris (Perancis) yang berlaku pada 2020 (Bose \& Raman, 2014). Para pihak menyepakati, semua negara perlu menyerahkan Intended Nationally Determined Contributions (INDC) untuk memerangi pemanasan global (Global 
CCS Institute, 2014). Istilah INDC diperkenalkan pada pertemuan COP ke-19, yang berarti identifikasi dari setiap negara dalam menguraikan secara umum tindakan iklim yang diambil pasca 2020 (WRI, 2017). Sedangkan, ketentuan kontribusi negara anggota untuk mengurangi emsi GRK secara nasional dalam Nationally Determined Contribution (NDC).

Seruan Lima untuk Aksi Iklim memiliki perbedaan dengan perjanjian lingkungan internasional lainnya. Seruan Lima untuk Aksi Iklim telah memenuhi syarat, dan mencerminkan prinsip dari "common but differentiated responsibilities and respective capabilities" (CBDRRC) namun dengan klausul "mengingat keadaan nasional yang berbeda" (Rajamani, 2015, p. 2). CBDRRC adalah pelafalan perlakuan berbeda untuk kewajiban pokok, dan pelaksanaan komitemen dengan berbagai negara berkembang yang sedang menerima bantuan : finansiil, teknis, pembangunan kapasitas (van Asselt, 2015, p. 1). Terpenuhinya syarat dalam Seruan Lima untuk Aksi Iklim, namun lemah dalam mengikat kepatuhan dan kewajiban anggota UNFCCC, badan ad hoc mengagendakan kembali perundingan (COP ke-21) pada tahun 2015 di Paris yang dihadiri sebanyak 36.276 peserta (UNFCCC, 2015, p. 2).

Dalam proses perundingan, terjadi perdebatan yang rumit dengan kemunculan isu baru sehingga memicu terjadinya konflik kepentingan di antara kelompok negara Like Minded Developing Countries (LMDC) seperti : Cina, India, Malaysia dan Indonesia dengan negara berkembang (developed countries) (Sinha, 2016). Salah satu point yang sulit disepakati yaitu mengenai diferensiasi. Difrensiasi adalah kategorisasi tingkat ekonomi negara dan tanggung jawabnya dalam upaya mengatasi perubahan iklim (Widyanto, 2015). Selain itu, mengenai bagaimana suatu perjanjian yang dibuat harus legally binding (mengikat secara hukum) dengan tingkatan tertinggi (Prakoso, 2015).

Perjanjian Paris bertujuan menekan laju suhu suhu global supaya tetap di bawah 2 atau $1,5^{\circ} \mathrm{C}$ pada abad ini berdasarkan INDC (Prihatnala \& Barry, 2016). Kelebihan Perjanjian Paris yaitu sepenuhnya menargetkan menghentikan kenaikan suhu, dengan mempertimbangkan keadaan dan kemampuan yang berbeda dari masing-masing negara (CRI, 2016). Transparansi (transparency) dan pembangunan kapasitas (capacity building) merupakan dua tambahan elemen, sehingga menjadi pertimbangan utama dan modalitas langkah kerja pemerintah di tingkat lokal lebih efektif dan efisien.

Berdasarkan Climate Change Performance Index (CCPI) 2017, Indonesia menempati urutan ke-22 mengenai transparansi politik iklim internasional melampaui Amerika Serikat. Salah satu faktor lemahnya transparansi Indonesia dalam politik iklim, terlihat dari 
implementasi aksi iklim dan minimnya akuntabilitas tata kelola hutan, sehingga praktek korupsi dalam pemberlakuan sistem perizinan yang masih terjadi. Untuk mencapai batas sebesar $2{ }^{\circ} \mathrm{C}$, pemerintah Indonesia disarankan untuk memperbaiki dan meningkatkan kebijakan perlindungan hutan (Burck, Marten, Bals, Bals, Dertinger, \& Uhlich, 2017, p. 3).

Indonesia terpilih mewakili Asia Pasifik sebagai anggota Paris Committee on Capacity Building (PCCB) selama perundingan dan berperan untuk mempengaruhi program-program penguatan kapasitas dalam implementasi Perjanjian Paris (Hariandja, 2016). Kapasitas merupakan suatu konsep yang dianggap sebagai suatu silsilah kelemahan cendikiawan dalam pembangunan dunia yang lebih besar (Khan, Sagar, Huq, \& Thiam, 2016, p. 4). Capacity building diperlukan dalam Perjanjian Paris dikarenakan :

1) Banyak negara berkembang, masih kekurangan akan pentingnya kapasitas untuk menjalankan aksi iklim.

2) Upaya peningkatan kapasitas membutuhkan koordinasi yang lebih besar, hubungan, monitoring, tinjauan dan pelaporan.

3) Perjanjian Paris menetapkan road map (peta jalan) pada pembangunan kapasitas (Dagnet \& Northrop, 2015).

Kebutuhan peta jalan untuk menjaga konsistensi perilaku dan membangun kepercayaan para aktor sehingga kredibilitas suatu perjanjian dapat terjaga dengan baik. Peta jalan Perjanjian Paris terdiri dari 3 bagian yaitu peta jalan peningkatan kapasitas umum, teknis dan kerangka kerja; sehingga sistem, kelembagaan, dan individu yang tekait peningkatan kapasitas di tahun 2020 dapat tersinergi, terukur, dan tercatat dengan baik (DITJEN PPI, 2017). Namun, pembahasan peta jalan didiskusikan secara inklusif untuk mematangkan aturan-aturan dan implementasi dari Perjanjian Paris pada COP selanjutnya.

\section{Kepentingan Indonesia}

Indonesia menempati posisi ke-tiga penyumbang emisi GRK setelah Amerika Serikat dan China (Ana, 2007). Emisi GRK Indonesia diperkirakan akan tumbuh 2\% per tahun dan mencapai 2.80 miliar ton pada tahun 2020 dan di tahun 2030 akan mencapai 3.60 milar ton (Firman \& Kurniawan, 2011). Selain itu, Indonesia menempati posisi ketiga penyumbang karbondiokasida $\left(\mathrm{CO}_{2}\right)$ terbesar di seluruh dunia (Koran Sindo, 2015). Sebanyak 60\%-70\% emisi GRK dihasilkan dari deforestasi dan ahli fungsi lahan (Hijauku, 2013).

Negara Indonesia sebagai salah satu subjek dari hukum internasional, dan aktor dominan dalam pengambilan keputusan mengambil langkah maju yaitu dengan meratifikasi Perjanjian Paris pada tanggal 05 Oktober 2015. Tindakan Indonesia dengan segera meratifikasi Perjanjian Paris tanpa menunggu terlebih dahulu negara lainnya, 
disebabkan pemerintah ingin berperan dalam mengambil keputusan yang terkait dengan implementasi Perjanjian Paris (Imelda H. , 2016). Sehingga Indonesia menjadi aktor kunci Perjanjian Paris dan kepentingan Indonesia dapat terwujud.

Sebelum Perjanjian Paris memasuki tahap entry into force, UNFCCC mengambil beberapa langkah sah yaitu langkah pertama negara-negara menandatangani perjanjian sebagai sinyal dukungan dan keinginan untuk menyelaraskan kebijakan domestiknya (Climate Nexus, 2015). Langkah kedua yaitu melakukan tindakan legal domestic, untuk bergabung secara formal (meratifikasi) perjanjian dan setuju untuk terikat dengan persyaratannya. Terakhir, dengan jumlah 55 negara anggota yang mencakup 55\% emisi secara global telah mendepositkan instrumen, penerimaan, persetujuan atau aksesinya dapat dinyatakan bergabung dan Perjanjian Paris resmi berlaku (IISD, 2016).

Setelah meratifikasi perjanjian Paris, Indonesia berkewajiban untuk memasang target INDC. Target INDC yang diajukan hingga tahun 2030 adalah sebesar 29\% dengan berfokus pada sektor energi, pangan dan sumber daya air serta pulau-pulau yang terdapat di wilayah Indonesia (Saturi \& Nugraha, 2015). Dari dua skenario aksi NDC, pemerintah Indonesia lebih berfokus pada sektor energi, limbah dan kehutanan (Arumingtyas, 2016). Hal ini dikarenakan sektor-sektor tersebut yang menyumbang output emisi GRK yang paling besar. Untuk mencapai target aksi NDC yang telah ditetapkan, pemerintah telah membuat Sistem Perhitungan Karbon Nasional Indonesia atau INCAS (Indonesian National Carbon Accounting System) (Setyorini V. P., 2016).

Namun masyarakat sipil menilai bahwa NDC Indonesia belum berpihak terhadap perubahan iklim. Komitemen dari NDC tidak menyertakan unsur-unsur spesifik, terukur, relevan, kegiatan yang berkredibel berbasiskan pembangunan jangka panjang yang bertangung jawab dan nol deforestasi (Nugraha, 2015). NDC Indonesia, tidak menyertakan energi terbarukan sebagai jalan keluar permanen dalam mengurangi emsi GRK. Proses penyusunan NDC juga tidak melibatkan pemangku kepentingan yang menjalankan dan menangani perubahan iklim sehingga terjadi kegamangan akibat ketiadaan leader actor (Fajar, 2015).

Pemerintah Indonesia meratifikasi Perjanjian Paris untuk mementingkan programprogram dari mekanisme pasar karbon, yang terbentuk dalam proses negosiasi oleh negaranegara maju (Firmansyah, 2015). Program tersebut yaitu berupa mitigasi dan adaptasi sebagai instrumen utama menangani perubahan iklim. Hal ini terlihat dari, tindakan Indonesia dengan menyusun suatu Rancangan Undang-undang Persetujuan Paris menjadi 
suatu Undang-undang (Munir, 2016). Undang-undang tersebut disahkan dan secara resmi bernama Undang-undang Nomor 16 Tahun 2016.

Kesigapan Indonesia membentuk UU tersebut dikarenakan pemerintah menginginkan dana iklim yang digelontorkan negara-negara maju dan lembaga keuangan dunia untuk kepentingan pembangunan. Negara-negara maju yang dimaksudkan yaitu suatu negara yang telah diidentifikasikan oleh Bank Dunia berdasarkan GDP (Gross Domestic Product) dan jumlah penduduk. Negara-negara maju, diwajibkan untuk berkontribusi dengan mengumpulkan dana $\$ 100$ miliar pertahunnya hingga tahun 2020 (VOA, 2015). Sedangkan lembaga keuangan dunia, yang diberikan tanggung jawab dalam mengelola pendanaan adalah Bank Dunia bekerjasama dengan berbagai lembaga donor dalam bentuk hibah maupun pinjaman.

Bank Dunia menilai bahwa perubahan mendasar dalam perannya mengurangi kemisikinan, dapat dilakukan dengan cara memusatkan kembali upaya pembiayaan dalam menjegal perubahan iklim (Harvey, 2016). Bank Dunia telah menyediakan uang dengan memproyeksikan dana sebesar \$ 29 miliar USD per tahun di 2020 pada Rencana Aksi Perubahan Iklimnya (Murphy, 2016). Bagi Bank Dunia, negara-negara yang memiliki penghasilan menengah seperti : Brasil, China, India, Indonesia, Meksiko, Turki dan lainnya memainkan peranan yang semakin penting untuk keahlian penyelesaian secara berkelanjutan dalam dunia ekonomi dan pembangunan dari berbagai negara (Zoellick, 2012, p. 70).

Salah satu lembaga donor yang dipercaya oleh Bank Dunia untuk menyalurkan uang tunai bagi aksi iklim yaitu GCF (Green Climate Fund/Dana Iklim Hijau). Pada tahun 2010, 194 negara anggota UNFCCC mendirikan GCF untuk membantu saluran pendanaan dari negara berkembang kepada negara sedang berkembang dan memformulasikan kebijakan ketahanan iklim dan bergeser ke jalur pembangunan rendah karbon (Naidoo, 2012, p. 2). Salah satu syarat penting dan wajib dipenuhi agar suatu negara mendapatkan dana segar adalah kepemilikan suatu komunitas, di mana kegiatan tersebut akan dilakukan dengan mengajukan proposal (Imelda, 2016).

Indonesia mengambil peluang dan mengakses dana CGF melalui entitas yang memiliki akses lingkup internasional dan dengan akses langsung (Imelda H. , 2016). Tujuan terjalinnya kerjasama Indonesia dengan GCF untuk mencapai tujuan-tujuannya dan melakukan reformasi infrastruktur hijau (Badan Kebijakan Fiskal Kementerian Keuangan RI, 2017). Namun sangat disayangkan bahwa, sebagian besar dana yang disalurkan untuk proyek-proyek perubahan iklim masih dalam bentuk loan, sehingga aktor non-negara 
seperti perusahaan yang ingin berinvestasi dengan sumber energi terbarukan tidak dapat menjadi prioritas untuk menjadi penerima dana (Agusmantono, 2015).

Indonesia adalah negara terbesar yang menerima dan menikmati pendanaan batu bara dari dunia internasional, khususnya dari negara China, Jepang dan Korea (Mulaika, 2016). Pemerintah mengincar kebijakan subsidi, infrastruktur ekspor, dan keringanan pajak untuk pembangkit listrik batu bara yang didukung oleh Bank Dunia melalui skema DPF dengan mengadopsi ekonomi rendah karbon (Villagerspost, 2017). Untuk memuluskan kepentingan pemerintah, telah disusun road map yang mengimplementasikan teknologi batu bara berefisiensi tinggi namun rendah emisi (High Efficiency Low Emissions/HELE) (Glienmourinsie, 2016). Sehingga, Indonesia dapat memainkan peranannya dalam memenuhi target INDC, permintaan konsumen akan kebutuhan energi, dan terlaksananya kegiatan pembangunan sesuai prinsip-prinsip ramah lingkungan.

Kepentingan pemerintah terhadap Perjanjian Paris, juga terlihat dari rencana pemanfaatan lahan gambut untuk memenuhi kebutuhan pangan masyarakat Indonesia. Kepentingan pemerintah atas program tersebut, dapat terlihat dengan adanya target seratus ribu hektar lahan gambut terbakar di Kalimantan yang akan dijadikan lahan pertanian (Laoli, 2015). Hal ini, akan diatur dalam Peraturan Pemerintah (PP) Nomor 71/2014 (Ningsih, 2015). Lahan gambut yang sudah terbakar dan rusak fungsinya, akan direstorasi oleh lembaga yang ditunjuk pemerintah. Lembaga yang berperan dalam melakukan restorasi lahan gambut tersebut yaitu Badan Restorasi Gambut (BRG).

\section{Badan Restorasi Gambut}

Pada tanggal 6 Januari 2016, BRG (Badan Restorasi Gambut) dibentuk berdasarkan Perpres No. 1 Tahun 2016 (Soepardi, 2016). BRG merupakan badan non-struktural di bawah dan bertanggung jawab secara langsung kepada presiden. Adapun tugas dari badan tersebut yaitu mengkoordinasikan dan memfasilitasi restorasi gambut di tujuh provinsi (Setiawan, 2016). Tujuan dibentuknya BRG sebagai bukti dari janji politik pemerintah Indonesia dalam forum pemimpin dunia COP ke-21, di Paris (Perancis) (Wibowo, 2015).

Indonesia memiliki luas lahan gambut terbesar ke-empat di dunia setelah Kanada (170 juta Ha), Rusia (150 juta Ha), dan Amerika Serikat (40 juta Ha) (Deputi Bidang Pengendalian Kerusakan Lingkungan, KLH, 2012, p. 1). Lahan gambut Indonesia memiliki nilai yang penting bagi dunia, karena dapat menyimpan emisi karbon 20 kali lipat dibandingkan hujan tropis biasa (Wihardandi, 2013). Menurut Departemen Pertambangan dan Energi (1989), luas lahan gambut yang ada di seluruh Indonesia diperkirakan berkisar 
17 juta Ha (Kementerian ESDM, 2016). Pemerintah mencatat lahan gambut di Indonesia dari tahun 2004-2011 mengalami penurunan (terdegradasi) sekitar 10,7\% di Sumatera, 17,2\% Kalimantan dan di Papua 28,8\% (Wahyunto, 2015).

Untuk mengatasi terjadinya penurunan jumlah lahan gambut di Indonesia, BRG menetapkan 'one map policy' yang tertuang dalam Perpres Nomor 9 Tahun 2016 yaitu melakukan moratorium dan review izin pemanfaatan lahan gambut, pengelolaan lahan, dan hutan produksi lestari (Mahbub, 2015). Penerapan 'one map policy' dilakukan dengan cara merealisasikan kebijakan satu peta sebagai dasar pemerintah dalam memperbaiki tata kelola di semua sektor termasuk sektor kehutanan (Santoso, 2016).

Secara struktural, BRG tidak bekerja sendiri. BRG melakukan koordinasi dan dukungan dengan Kementerian LHK (Lingkungan Hidup dan Kehutanan) berupa kebijakan teknis namun kewenangan yang diberikan masih tumpang tindih sehingga menimbulkan ketidakpastian serta merugikan banyak pihak (Tuti, 2016). Provinsi yang menjadi target utama dalam merestorasi lahan gambut membentuk TRGD (Tim Restorasi Gambut Daerah) untuk memperkuat kelembagaan, koordinasi pusat-daerah dan kerjasama di antara pihak yang terkait (Setyorini V. P., 2017). Salah satu kerja nyata TRGD yaitu melakukan sosialisasi dan pembuatan sumur bor di Kabupaten Pulang Pisau yang merupakan salah satu satu daerah prioritas restorasi gambut (Donny, 2016).

Untuk merestorasi 2 juta hektar lahan gambut, diperkirakan BRG membutuhkan dana sebesar Rp. 50 triliun (Sukmana, 2015). BRG mendapatkan pendanaan dari pemerintah melalui anggaran APBN, kesepakatan perdagangan karbon dan dari berbagai program REDD+. Pendanaan terhadap kinerja BRG tidak terlepas dari kerjasama dari berbagai aktor. Amerika Serikat melalui USAID telah mengucurkan dana sebesar Rp 634 miliar (Nawangwulanh, 2016). Sedangkan Norwegia memberikan dana 50 juta dolar AS (Foead, 2016). Dari sisi teknis, BRG bekerjasama dengan lembaga Indonesia Climate Change Trust Fund (ICCTF) dengan menyetujui suatu Memorandum of Understanding (MoU) untuk meningkatkan tata kelola lahan gambut dan menerapkan rencana-rencana strategis kedua lembaga (ICCTF, 2017).

BRG telah menyiapkan road map, bagi investor yang ingin berinvestasi di lahan gambut yang telah rusak seluas 6 juta hektar dan dapat dimanfaatkan sebagai lahan untuk tanamanan industri (HTI) seperti : kertas, kayu lapis dan lain sebagainya (Prabowo, 2016). Selanjutnya, Kementerian LHK dan BRG menawarkan perusahaan HTI dengan skema land swap yang mana 40\% lahan konsesinya (kawasan lahan gambut), akan ditetapkan sebagai fungsi lindung dan sebagai gantinya akan disiapkan lahan mineral sebagai hadiah 
(Saragih, 2017). Jadi, perusahaan dan masyarakat adat di sekitar lahan konsesi, dapat bekerjasama maupun berinteraksi yang saling menguntungkan kedua pihak (simbiosis mutualisme) untuk memanfaatkan lahan gambut agar tercapai kepentingan bersama.

\section{KESIMPULAN}

Perjanjian Paris memberikan kebijakan alternatif kepada dunia, khususnya pemerintah Indonesia untuk menjalankan pembangunan sembari menekan perubahan iklim dengan menerapkan prinsip-prinsip ramah lingkungan. Perjanjian Paris telah mengalami berbagai proses perundingan dan melibatkan banyak aktor. Namun, pada perjalanannya Perjanjian Paris menghadapi tantangan dari negara-negara industri minyak bumi. Sebagian kalangan menduga, Perjanjian Paris hanya mementingkan kepentingan negara-negara maju melalui penawaran mekanisme pasar karbon yang diperuntukkan bagi negara-negara miskin maupun berkembang yang terkena dampak lingkungan akibat kegiatan industri negaranegara maju.

Indonesia sebagai negara pinggiran (periphery) dan subordinan negara-negara maju (center) dalam geopolitik, meratifikasi Perjanjian Paris agar kepentingan Indonesia di bidang pembangunan yang berawawasan lingkungan tidak terhambat dan mendapatkan dukungan serta kepercayaan dunia internasional dari sisi pendanaan. Kepentingan tersebut dapat terlihat dari program-program pembangunan ambisus yang direncanakan oleh pemerintah salah satunya dengan memanfaatkan lahan gambut. Melalui BRG, pemerintah Indonesia dapat mengimplementasikan kepentingannya di bawah payung Perjanjian Paris. Sehingga, Indonesia sebagai salah satu negara dengan kepemilikan salah satu lahan gambut terluas di dunia, meningkatkan posisi tawar dalam setiap perundingan maupun keputusan politik luar negeri yang dibuat secara global oleh setiap aktor yang terlibat.

Untuk mengejar kepentingan nasional, pemerintah Indonesia hendaknya mengerahkan sumber daya yang terdapat di luar negeri sebagai modalitas untuk pembangunan nasional. Tentu saja, diperlukan gerakan bersama dalam pembangunan (collective development) di antara aktor-aktor yang terikat dan terlibat. Pengertian collective development dalam hal ini yaitu suatu tindakan bersama (kekeluargaan) dari setiap organisme politik yang menyertakan etik dan dapat diterima berbagai pihak dengan tujuan untuk memenuhi kebutuhan dasar bersama. Salah satu modalitas tersebut terlihat dari warisan Indonesia, yang berupa akumulasi perilaku dalam bentuk kebiasaan (budaya) gotong-royong yang telah melekat di setiap individu dan sudah ada sejak dahulu kala. Dengan demikian, 
kepentingan yang diperjuangkan dan telah dicapai dapat dimanfaatkan untuk kebutuhan bersama.

Keterlibatan dan peranan aktor-aktor non-negara dalam aksi perubahan iklim terutama keberlangsungan dan restorasi lahan gambut sangatlah penting. Aktor-aktor yang dapat dilibatkan meliputi : swasta, masyarakat sipil dan adat, media, akademisi dan LSM. Di pihak swasata, pemerintah sebaiknya mengambil sikap tegas dengan menekan perusahaan apabila perusahaan tersebut belum bersedia untuk mengubah fungsi lahannya yang merupakan kawasan gambut menjadi fungsi pelindungi, penyangga dan menyimpan karbon. Perempuan yang merupakan bagian masyarakat lokal, dapat dilibatkan dan berpartisipasi aktif dalam pengelolaan lahan gambut agar berkontribusi bagi kesejahteraan keluarga mereka. Karena, ketika perempuan dilibatkan dalam upaya restorasi maka hasilnya akan menjadi lebih baik dan mereka dapat mendidik anak-anak mereka untuk menjaga ekosistem lahan gambut. Selain itu, pemerintah dapat menghidupkan kembali Jambore Masyarakat Gambut dengan mengadakan program-program di tingkat berskala lokal dan internasional yang melibatkan negara-negara lahan gambut dan mempromosikannya melalui media-media. Yang terakhir, para akedemisi dan lembaga pendidikan dapat berkerjasama dengan membentuk laboratorium gambut untuk mengedukasi masyarakat sekitar mengenai pentingnya lahan gambut bagi kehidupan.

\section{DAFTAR PUSTAKA}

\section{Buku:}

Ashari, K. (2015). Kamus Hubungan Internasional. Bandung: Nuansa Cendekia.

Burchill, S., \& Linklater, A. (2009). Teori-Teori Hubungan Internasional. Bandung: Penerbit Nusa Media.

Pieterse, J. N. (2010). Development Theory Deconstructions/Reconstructions. London: SAGE Publications Ltd.

Tsani, M. B. (1990). Hukum Dan Hubungan Internasional. Yogyakarta: Liberty.

Winarno, B. (2011). Isu-Isu Global Kontemporer. Yogyakarta: Center for Academic Publishing Service (CAPS).

\section{Jurnal:}

Zoellick, R. B. (2012). Why We Still Need The Word bank. Foreign Affairs , 66-78.

\section{Tulisan/artikel:}


Naidoo, K. (2012, Maret). The Green Climate Fund and the role of the World Bank. CLIMATE FINANCE AFRICA . Westlands, Nairobi, Kenya: PACJA.

\section{Laporan:}

Burck, J., Marten, F., Bals, C., Bals, C., Dertinger, A., \& Uhlich, T. (2017). Climate Change Performance Index Results 2017. Berlin: Germanwatch.

Deputi Bidang Pengendalian Kerusakan Lingkungan, KLH. (2012). Strategi Nasional Pengelolaan Lahan Gambut Berkelanjutan di Indonesia. Jakarta: Kementerian Lingkungan Hidup.

\section{Sumber Online:}

Agusmantono. (2015, Desember 05). Opini : Indonesia di COP22: Global Climate Fund Untuk Siapa? Retrieved April 20, 2017, from http://www.mongabay.co.id/2016/12/05/opini-indonesia-di-cop22-global-climatefund-untuk-siapa/

Ana. (2007, November 21). RI Pengemisi Gas Rumah Kaca Ketiga Terbesar. Retrieved Januari 09, 2017, from detikNews: http://news.detik.com/berita/855467/ri-pengemisigas-rumah-kaca-ketiga-terbesar

Arumingtyas, L. (2016, Agustus 15). Bahas NDC, Pemerintah Masih Belum Satu Suara. Retrieved April 07, 2017, from http://www.mongabay.co.id/2016/08/15/bahas-ndcpemerintah-masih-belum-satu-suara/

Badan Kebijakan Fiskal Kementerian Keuangan RI. (2017, Mei 26). Green Climate Fund High Level Segment. Retrieved April 21, 2017, from http://www.fiskal.kemenkeu.go.id/dw-kontenview.asp?id=20170503163817220590859

Bose, I., \& Raman, M. (2014, Desember 15). Konferensi Perubahan Iklim di Lima Peru Ditutup. Retrieved Maret 30, 2017, from http://beritabumi.or.id/konferensi-perubahaniklim-di-lima-peru-ditutup/

Carpenter, C. (2008, November 01). The Bali Road Map: Key Issues Under Negotiation. Retrieved Februari 07, 2017, from http://www.undp.org/content/undp/en/home/librarypage/environmentenergy/climate_change/climate_change_andpoverty/the_bali_road_mapkeyissuesunde rnegotiation.html

Christine, R. V. (2015, April 20). Bumi Makin Panas, Peningkatan Suhu Global Sentuh Rekor pada Maret 2015. Retrieved Maret 04, 2017, from http://www.tribunnews.com/iptek/2015/04/20/bumi-makin-panas-peningkatan-suhuglobal-sentuh-rekor-pada-maret-2015?page $=2$

Climate Nexus. (2015). Steps for Entry into Force of the Paris Agreement. Retrieved April 08, 2017, from http://climatenexus.org/about-us/analysis/steps-entry-force-parisagreement

CRI. (2016, Januari 05). Dunia Tetap Hadapi Tugas Berat pasca Perjanjian Paris. Retrieved April 06, 2017, from http://indonesian.cri.cn/201/2016/01/05/1s159116.htm 
Dagnet, Y., \& Northrop, E. (2015, Desember 18). 3 Reasons Why Capacity Building Is Critical for Implementing the Paris Agreement. Retrieved Februari 21, 2017, from http://www.wri.org/blog/2015/12/4-signs-paris-agreement-start-new-era-internationalclimate-action

DITJEN PPI. (2017). Menghampar Peta Jalan Aksi Pemberdayaan Iklim. Retrieved Februari 07, 2017, from http://ditjenppi.menlhk.go.id/berita-ppi/2704-menghamparpeta-jalan-aksi-pemberdayaan-iklim.html

Donny, J. (2016, September 13). TRGD Pulang Pisau Mulai Lakukan Sosialisasi. Retrieved Desember 19, 2017, from http://www.borneonews.co.id/berita/40260-trgdpulang-pisau-mulai-lakukan-sosialisasi

DW. (2007, 12 16). Bali Roadmap Disepakati. Retrieved Maret 23, 2017, from http://www.dw.com/id/bali-roadmap-disepakati/a-3007129

Fajar, J. (2015, September 10). Pengamat : INDC Indonesia Berpotensi Bermasalah Besar. Retrieved April 18, 2017, from http://www.mongabay.co.id/2015/09/10/pengamatindc-indonesia-berpotensi-bermasalah-besar/

Firman, M., \& Kurniawan, I. (2011, Desember 23). 2030, Emisi Gas Rumah Kaca RI 3,6 $M \quad T o n$. Retrieved Januari 07, 2017, from Viva.co.id: http://teknologi.news.viva.co.id/news/read/274338-2030-emisi-gas-rumah-kacaindonesia-3-6m-ton

Firmansyah. (2015, Desemebr 13). Kesepakatan Paris Dikritik. Retrieved April 17, 2017, from http://sains.kompas.com/read/2015/12/13/11322441/Kesepakatan.Paris.Dikritik.

Foead, N. (2016, Februari 04). Norwegia Gelontorkan 50 Juta Dolar AS Untuk Dukung Restorasi Gambut di Indonesia . Retrieved Mei 27, 2017, from http://nasional.harianterbit.com/nasional/2016/02/04/55352/0/25/NorwegiaGelontorkan-50-Juta-Dolar-AS-Untuk-Dukung-Restorasi-Gambut-di-Indonesia

Glienmourinsie, D. (2016, September 07). Pemerintah Susun Roadmap Tenaga Batu Bara Emisi Rendah. Retrieved April 27, 2017, from https://ekbis.sindonews.com/read/1137271/34/pemerintah-susun-roadmap-tenagabatu-bara-emisi-rendah-1473178396

Global CCS Institute. (2014, Desember 19). A technical view on the Lima Call for Climate Action. $\quad$ Retrieved $\quad$ Maret 31, 2017, from https://www.globalccsinstitute.com/insights/authors/MarkBonner/2014/12/19/technica l-view-lima-call-climate-action?author=NzU3

Guerrero, L. (2011, Oktober 13). UNFCCC 101. Retrieved Maret 10, 2017, from http://www.greenpeace.org/seasia/id/blog/unfccc-101/blog/37307/

Hariandja, R. Y. (2016, November 11). Pengaruhi Penerapan Perjanjian Paris. Retrieved April 07, 2017, from http://www.mediaindonesia.com/index.php/news/read/76896/pengaruhi-penerapanperjanjian-paris/2016-11-11

Harvey, F. (2016, April 07). World Bank to spend $28 \%$ of investments on climate change projects. $\quad$ Retrieved April 07, 2017, from 
https://www.theguardian.com/environment/2016/apr/07/world-bank-investmentsclimate-change-environment

Hijauku. (2013, November 01). Peringkat Negara Penyebab Perubahan Iklim. Retrieved Januari 17, 2017, from Hijauku.com: http://www.hijauku.com/2013/11/01/peringkatnegara-penyebab-perubahan-iklim/

ICCTF. (2017, Januari 27). Restorasi Gambut Butuh Prioritas Pendanaan. Retrieved April 23, 2017, from http://icctf.or.id/restorasi-gambut-butuh-prioritas-pendanaan/

IESR. (2011, November 29). Konferensi PBB Mengenai Perubahan Iklim di Durban. Retrieved Maret 11, 2017, from http://iesr.or.id/2011/11/konferensi-pbb-mengenaiperubahan-iklim-di-durban/

IISD. (2016, September 20). New Ratifications Announced for Paris Agreement. Retrieved April 08, 2017, from http://sdg.iisd.org/news/new-ratifications-announced-for-parisagreement/

Imelda, H. (. (2016, Maret 21). Green Climate Fund : Perkembangan dan Peluang Bagi Indonesia. Retrieved April 19, 2017, from http://iesr.or.id/2016/03/green-climatefund-perkembangan-dan-peluang-bagi-indonesia/

Imelda, H. (. (2016, Oktober 17). Menuai Pundi untuk Pembangunan Selaras Perubahan Iklim melalui Green Climate Fund $(G C F)$. Retrieved April 19, 2017, from http://iesr.or.id/2016/10/menuai-pundi-untuk-pembangunan-selaras-perubahan-iklimmelalui-green-climate-fund-gcf/

Imelda, H. (2016, April 25). Indonesia dalam Paris Agreement : Lebih dari Sekedar Kontribusi. Retrieved April 06, 2017, from http://iesr.or.id/2016/04/indonesia-dalamparis-agreement-lebih-dari-sekedar-kontribusi/

Jurnal Bumi. (2016). KTT Bumi. Retrieved Desember 19, 2016, from JURNAL BUMI: https://jurnalbumi.com/ktt-bumi/

Kementerian ESDM. (2016, Desember 17). Gambut Indonesia Luas Tersebar dan Mudah Terbakar. Retrieved April 07, 2017, from GEOMAGZ: http://geomagz.geologi.esdm.go.id/gambut-indonesia-luas-tersebar-dan-mudahterbakar/

Kementerian Luar Negeri Republik Indonesia. (2016, November 01). Pemerintah RI Penuhi Janji Ratifikasi Perjanjian Paris. Retrieved Februari 17, 2017, from http://kemlu.go.id/id/berita/Pages/Pemerintah-RI-Penuhi-Janji-Ratifikasi-PerjanjianParis.aspx

Khan, M., Sagar, A., Huq, S., \& Thiam, P. K. (2016). Capacity building under the Paris Agreement. Berlin: European Capacity Building Initiative.

Koran Sindo. (2015, 10 27). Indonesia Penyumbang Polusi Ketiga Terbesar Dunia. Retrieved Desember 17, 2017, from Koran Sindo: http://koransindo.com/news.php? $r=0 \& n=18 \&$ date $=2015-10-27$

Laoli, N. (2015, November 16). Kemtan: Lahan gambut terbakar untuk pertanian. Retrieved April 23, 2017, from http://industri.kontan.co.id/news/kemtan-lahangambut-terbakar-untuk-pertanian 
Lova, P. A. (2013, April 22). Sejarah Singkat UNFCCC. Retrieved Maret 20, 2017, from http://www.satuharapan.com/read-detail/read/sejarah-singkat-unfccc

Mahbub, A. (2015, Desember 01). COP21 Paris, Jokowi: Badan Restorasi Gambut Segera Dibentuk. Retrieved Januari 17, 2017, from Tempo.co: https://m.tempo.co/read/news/2015/12/01/206723648/cop21-paris-jokowi-badanrestorasi-gambut-segera-dibentuk

Maryam, Y. (2011, Desember 01). Tanya Jawab Seputar Konferensi PBB Mengenai Perubahan Iklim di Durban. Retrieved Februari 17, 2017, from http://iesr.or.id/2011/12/tanya-jawab-seputar-konferensi-pbb-mengenai-perubahaniklim-di-durban/

Morgan, J. (2015, Desember 14). 4 Signs the Paris Agreement Is the Start of a New Era in International Climate Action. Retrieved Februari 09, 2017, from http://www.wri.org/blog/2015/12/4-signs-paris-agreement-start-new-era-internationalclimate-action

Mulaika, H. (2016, November 18). Subsidi Batu Bara \& Janji Paris. Retrieved Mei 01, 2017, from http://koran.bisnis.com/read/20161118/251/603812/subsidi-batu-barajanji-paris

Munir, D. (2016, Oktober 20). DPR RI Sahkan Undang-undang Persetujuan Paris Tentang Perubahan Iklim. Retrieved April 19, 2017, from http://apeksi.id/index.php/12berita/nasional/1129-dpr-ri-sahkan-undang-undang-persetujuan-paris-tentangperubahan-iklim

Murphy, T. (2016, April 11). World Bank shows climate change the money. Retrieved April 7, 2017, from https://www.globalcitizen.org/en/content/world-bank-showsclimate-change-the-money/

Nawangwulanh, M. (2016, Januari 09). Amerika Kucurkan Rp 634 Miliar untuk Proyek Hutan dan Gambut . Retrieved Mei 28, 2017, from https://m.tempo.co/read/news/2016/01/09/206734452/amerika-kucurkan-rp-634miliar-untuk-proyek-hutan-dan-gambut

Ningsih, D. (2015, November 18). Lahan Gambut Bekas Terbakar Bisa untuk Pertanian. Retrieved Mei 07, 2017, from http://www.beritasatu.com/ekonomi/323059-lahangambut-bekas-terbakar-bisa-untuk-pertanian.html

Nugraha, I. (2015, September 21). Koalisi Masyarakat Sipil Nilai Dokumen INDC Belum Jawab Persoalan Perubahan Iklim. Retrieved April 14, 2017, from http://www.mongabay.co.id/2015/09/21/koalisi-masyarakat-sipil-nilai-dokumen-indcbelum-jawab-persoalan-perubahan-iklim/

Peterman, K. (2014, Desember 15). 'Lima Call for Climate Action' Falls Short of What Science Urges and People Demand. Retrieved Maret 30, 2017, from http://www.huffingtonpost.com/keith-peterman/lima-call-for-climateact_b_6323186.html

Prabowo, D. (2016, Agustus 24). Wapres Minta Badan Restorasi Gambut Siapkan "Roadmap" Investasi . Retrieved April 27, 2017, from 
http://nasional.kompas.com/read/2016/08/24/15313571/wapres.minta.badan.restorasi.g ambut.siapkan.roadmap.investasi.

Prakoso, D. L. (2015, Desember 04). 6 Hal Penting dari Konferensi Perubahan Iklim Paris yang Wajib Diketahui. Retrieved Maret 31, 2017, from https://news.idntimes.com/world/luthfan/6-hal-penting-dari-konferensi-perubahaniklim-paris/full

Prihatnala, S., \& Barry, M. A. (2016, Desember 02). Trump Terpilih, Persetujuan Paris Terancam. Retrieved April 6, 2017, from http://arsip.gatra.com/2016-1202/majalah/artikel.php?pil $=23 \& i d=163300$

Rajamani, L. (2015, Juni). Differentiation in a 2015 Climate Agreement. Retrieved Maret 31, 2017, from https://www.c2es.org/publications/differentiation-2015-climateagreement

Santoso, A. B. (2016, Februari 17). Mematangkan Konsep Pembangunan Rendah Emisi Berbasis Lahan di Indonesia. Retrieved Januari 14, 2017, from http://www.tribunnews.com/tribunners/2016/02/17/mematangkan-konseppembangunan-rendah-emisi-berbasis-lahan-di-indonesia

Saragih, S. (2017, Maret 02). Pengusaha Minta Diterapkan Bertahap. Retrieved April 30, 2017, from http://koran.bisnis.com/read/20170302/452/633230/pengusaha-mintaditerapkan-bertahap

Saturi, S., \& Nugraha, I. (2015, September 02). Indonesia Targetkan Penurunan Emisi Karbon 29\% pada 2030. Retrieved April 14, 2017, from http://www.mongabay.co.id/2015/09/02/indonesia-targetkan-penurunan-emisi-karbon29-pada-2030/

Setiawan, A. (2016, Januari 25). Inilah Perpres No. 1 Tahun 2016 tentang Badan Restorasi Gambut. Retrieved November 23, 2016, from Sekretariat Kabinet Republik Indonesia: http://setkab.go.id/inilah-perpres-no-1-tahun-2016-tentang-badan-restorasi-gambut/

Setyorini, V. P. (2016, April 03). Indonesia matangkan NDC penuhi perjanjianiklim paris. Retrieved April 07, 2017, from http://www.antaranews.com/berita/553298/indonesiamatangkan-ndc-penuhi-perjanjian-iklim-paris

Setyorini, V. P. (2017, Januari 03). Langkah awal perjalanan panjang restorasi gambut Indonesia. $\quad$ Retrieved Februari 08, 2017, from http://www.antaranews.com/berita/604700/langkah-awal-perjalanan-panjang-restorasigambut-indonesia

Sinha, A. (2016, Oktober 07). After 'Like Minded Developing Countries' meet, prospects for climate change negotiations 'minimalist'. Retrieved April 01, 2017, from http://indianexpress.com/article/world/climate-change/after-like-minded-developingcountries-meet-prospects-for-climate-change-negotiations-appear-bleak/

Soepardi, H. H. (2016, Januari 13). Presiden Umumkan Tebentunya Badan Restorasi Gambut. Retrieved November 29, 2016, from antaranews: http://www.antaranews.com/berita/539751/presiden-umumkan-terbentuknya-badanrestorasi-gambut 
Sukmana, Y. (2015, November 26). Rehabilitasi 2 Juta Hektar Lahan Gambut Butuh Rp 50 Triliun. Retrieved April 10, 2017, from http://bisniskeuangan.kompas.com/read/2015/11/26/114900426/Rehabilitasi.2.Juta.He ktar.Lahan.Gambut.Butuh.Rp.50.Triliun

Syafputri, E. (2012, Desember 09). Indonesia minta negara maju berkomitmen kurangi emisi. Retrieved Maret 19, 2017, from http://www.antaranews.com/berita/347697/indonesia-minta-negara-majuberkomitmen-kurangi-emisi

The World Bank. (2012, November 18). Laporan Baru Menganalisa Risiko Peningkatan Suhu Bumi Sebesar 4 Derajat di Akhir Abad. Retrieved Maret 04, 2017, from The World Bank Group: http://www.worldbank.org/in/news/pressrelease/2012/11/18/new-report-examines-risks-of-degree-hotter-world-by-end-ofcentury

Tuti. (2016, Mei 31). KLHK Dukung Badan Restorasi Gambut (BRG) Percepat Restorasi Di 7 Provinsi . Retrieved April 30, 30, from http://www.fordamof.org/berita/post/2801

UNFCCC. (2015, Desember 01). Provisional list of participants. Retrieved Maret 31, 2017, from unfccc.int/resource/docs/2015/cop21/eng/misc02p01.pdf

van Asselt, H. (2015, Januari). Reconciling differential treatment and the international regulation of . Retrieved Maret 31, 2017, from https://www.seiinternational.org/mediamanager/documents/Publications/Climate/SEI-PB-2015International-aviation-emissions-differentiation.pdf

Villagerspost. (2017, Januari 28). Salah Arah Kebijakan Pendanaan Batu Bara Bank Dunia. Retrieved April 22, 2017, from http://villagerspost.com/todays-feature/salaharah-kebijakan-pendanaan-batubara-bank-dunia/

VOA. (2015, Desember 09). Perdebatan tentang Negara Kaya dan Miskin Membayangi Konferensi Iklim PBB. Retrieved April 20, 2017, from http://www.voaindonesia.com/a/perdebatan-tentang-negara-kaya-dan-miskinmembayangi-konferensi-iklim-pbb/3094097.html

Wahyunto. (2015). Lahan gambut di Indonesia: istilah/definisi, klasifikasi, luasan, penyebaran dan pemutakhiran data spasial lahan gambut. Retrieved April 08, 2017, from http://www.cifor.org/ipn-toolbox/wp-content/uploads/pdf/A1.pdf

Wibowo, A. (2015, November 30). Presiden sampaikan pidato di COP21 UNFCCC. Retrieved Januari 08, 2017, from antaranews.com: http://www.antaranews.com/berita/532416/presiden-sampaikan-pidato-di-cop21unfecc

Widyanto, U. (2015, Desember 04). Begini Alotnya Perundingan di Konferensi Iklim Paris. $\quad$ Retrieved Maret 31, 2017, from https://m.tempo.co/read/news/2015/12/04/206724859/begini-alotnya-perundingan-dikonferensi-iklim-paris

Wihardandi, A. (2013, September 30). Lahan Gambut Indonesia, Bom Waktu Emisi Karbon Dunia. Retrieved Desember 04, 2016, from Mongabay Indonesia: 
http://www.mongabay.co.id/2013/09/30/lahan-gambut-indonesia-bom-waktu-emisikarbon-dunia/

WRI. (2017). What is an INDC? Retrieved Maret 31, 2017, from http://www.wri.org/indcdefinition

WWF. (2017). Sekilas Tentang Protokol Kyoto. Retrieved Maret 07, 2017, from http://www.wwf.or.id/tentang_wwf/upaya_kami/iklim_dan_energi/solusikami/negotiat ion_kyoto_p.cfm 